Gut, 1973, 14, 255-262

\title{
An analysis of the reliability of detection and diagnostic value of various pathological features in Crohn's disease and ulcerative colitis
}

\author{
M. G. COOK AND M. F. DIXON \\ From the Departments of Surgery and Pathology, University of Leeds
}

SUMMARY Two pathologists have independently applied 95 separate pathological criteria to 50 cases of inflammatory large bowel disease firmly diagnosed clinically as 25 cases of Crohn's disease and 25 cases of ulcerative colitis.

The observer agreement in the recording of each feature has been calculated and correlations have been made between the pathological features and the final agreed diagnosis in order to obtain an estimate of the value of each feature in differential diagnosis.

The features which have been found to be most accurately observed and useful in the diagnosis of Crohn's disease include confluent linear ulcers, deep fissures, an aggregated inflammatory pattern, and sarcoid-like granulomata. The features which have been shown to be most accurate and valuable in the diagnosis of ulcerative colitis include a 'healed granular' mucosa, a continuous inflammatory pattern, an irregular gland pattern, and the absence of fissures.

The authors consider that the use of such accurate and valuable pathological criteria in the examination of inflammatory bowel disease would facilitate retrospective correlation with the clinical findings and help to clarify those intermediate cases which are at present a source of diagnostic difficulty.

Crohn's disease and ulcerative colitis, although fully described by many workers, including Rappaport, Burgoyne, and Smetana (1951), Van Patter, Bargen, Dockerty, Feldman, Mayo, and Waugh (1954), Morson (1968), and Mottet (1971), continue to present a problem in differential diagnosis. The two diseases share many pathological features and the distinguishing points are often subtle and ill defined, hence there have been many attempts to delineate the two (Lennard-Jones, Lockhart-Mummery, and Morson, 1968; McGovern, 1969; Kent, Ammon, and DenBesten, 1970). At present some cases which are difficult to classify pathologically may show clinical or radiological signs which enable at least a working diagnosis to be made. This seems unsatisfactory from a pathological point of view; the pathologist may merely endorse the clinical classifications by selecting those features which fit the clinical diagnosis. This can be taken as support for what may be an overrigid simplification by the essentially pragmatic clinician and may be masking a diversity of diseases which if investigated separately

Received for publication 1 February 1973. would more readily be understood in pathogenetic terms.

It seems appropriate therefore that the pathological diagnosis of this group of diseases should be analysed as objectively as possible with a view eventually to classifying them into pathological rather than largely clinical entities. With this in mind the present study had two main objectives. First, we have set out to determine the degree of observer variation between two pathologists in their assessment of the macroscopic and histopathological features, the definition of these having been agreed beforehand. Our second objective was to correlate the detailed grading of these pathological features with the clinically and pathologically agreed diagnosis in order to assess their value in differential diagnosis.

\section{Methods and Materials}

The observations were made on 50 specimens of inflammatory bowel disease which had been resected between 1957 and 1971 and were selected randomly by a congruential method, using program SAS 59 implemented on a Mathatronics Mathatron 848 
biostatistician computer, from two groups: Crohn's disease and ulcerative colitis, which had been firmly diagnosed clinically. The 25 cases of Crohn's disease were qualified in that they all had large bowel involvement so that they were more directly comparable with the 25 cases of ulcerative colitis.

The specimens had been stored in $10 \%$ formal saline and the original paraffin wax blocks and stained sections were also available.
The 95 criteria to be applied to these specimens were derived from the publications of Morson (1968), Mottet (1971), McGovern (1969), Williams (1964), Skinner, Whitehead, and Piris (1971), Filipe and Dawson (1970), Davis, Dockerty, and Mayo (1955), Montes, Milch, Berman, and Culver (1970), and from our own experience. They are enumerated in table I. This table also demonstrates the way in which each feature was recorded in some cases by grading into

\begin{tabular}{|c|c|c|c|c|c|c|}
\hline & \multicolumn{6}{|l|}{ Grade } \\
\hline & 1 & 2 & 3 & 4 & 5 & 6 \\
\hline \multicolumn{7}{|l|}{ Macroscopy } \\
\hline $\begin{array}{l}\text { Length of ileum }(\mathrm{cm}) \\
\text { Length of colon }(\mathrm{cm}) \\
\text { Anal canal } \\
\text { Appendix }\end{array}$ & $\begin{array}{l}0 \\
0 \\
\text { Absent } \\
\text { Absent }\end{array}$ & $\begin{array}{l}1-5 \\
1-30 \\
\text { Normal } \\
\text { Present }\end{array}$ & $\begin{array}{l}6-10 \\
31-60 \\
\text { Ulcerated }\end{array}$ & $\begin{array}{l}11-20 \\
61-80 \\
\text { Sinus or fistula }\end{array}$ & $\begin{array}{l}21-40 \\
81-100 \\
\text { Mucosal tag }\end{array}$ & $\begin{array}{l}>40 \\
>100 \\
\text { Skin tag }\end{array}$ \\
\hline Site of main disease & Rectum & $\begin{array}{l}\text { Rectum and } \\
\text { proximal } \\
\text { extension }\end{array}$ & $\begin{array}{l}\text { Total large } \\
\text { bowel }\end{array}$ & $\begin{array}{l}\text { Patchy large } \\
\text { bowel }\end{array}$ & $\begin{array}{l}\text { Ileum and large } \\
\text { bowel }\end{array}$ & $\begin{array}{l}\text { Colon, sparing } \\
\text { rectum }\end{array}$ \\
\hline $\begin{array}{l}\text { Length of main disease } \\
\text { Length of normal margin }\end{array}$ & $1-10$ & $11-30$ & $31-60$ & $61-80$ & $81-100$ & $>100$ \\
\hline $\begin{array}{l}\text { Proximal } \\
\text { Distal }\end{array}$ & $\begin{array}{l}\mathbf{0} \\
\mathbf{0}\end{array}$ & $\begin{array}{l}1-5 \\
\text { To anal canal }\end{array}$ & $\begin{array}{l}6-10 \\
1-10\end{array}$ & $\begin{array}{l}11-20 \\
11-20\end{array}$ & $\begin{array}{l}21-30 \\
21-30\end{array}$ & $\begin{array}{l}>30 \\
>30\end{array}$ \\
\hline Number of skip lesions & $\mathbf{0}$ & 1 & 2 & 3 & 4 & 5 or more \\
\hline $\begin{array}{l}\text { Site of skip lesions } \\
\text { Length }(\mathrm{cm}) \text { of skip lesions } \\
\text { (average) }\end{array}$ & $\begin{array}{l}\mathbf{0} \\
\mathbf{0}\end{array}$ & $\begin{array}{r}\text { Ileum } \\
1-3\end{array}$ & $\begin{array}{l}\text { Caecum } \\
4-6\end{array}$ & $\begin{array}{c}\text { Colon } \\
7-10\end{array}$ & $\begin{array}{l}\text { Rectum } \\
11-20\end{array}$ & $\begin{array}{l}\text { Ileum and colon } \\
>20\end{array}$ \\
\hline $\begin{array}{l}\text { Thickness of wall in diseased } \\
\text { area }\end{array}$ & Normal & Thick & Thin & & & \\
\hline $\begin{array}{l}\text { Width of lumen in diseased area } \\
\text { Internal fistulae }\end{array}$ & $\begin{array}{l}\text { Normal } \\
\text { Present }\end{array}$ & $\begin{array}{l}\text { Narrow } \\
\text { Absent }\end{array}$ & Dilated & & & \\
\hline Number of polyps & 0 & $0-20$ & $21-100$ & $>100$ & & \\
\hline Average polyp size (mm) & 0 & $1-4$ & $5-8$ & $>8$ & $\begin{array}{l}>8 \text { with } \\
\text { bridging }\end{array}$ & \\
\hline $\begin{array}{l}\text { Character of mucosa in area } \\
\text { of disease }\end{array}$ & $\begin{array}{l}\text { Healed or } \\
\text { granular }\end{array}$ & $\begin{array}{l}\text { Superficial, } \\
\text { discrete }\end{array}$ & $\begin{array}{l}\text { Superficial, } \\
\text { irregular, } \\
\text { confluent }\end{array}$ & $\begin{array}{l}\text { Superficial, } \\
\text { linear confluent }\end{array}$ & Deep fissure & Cobblestoning \\
\hline Adhesions & Present & Absent & & & & \\
\hline \multicolumn{7}{|l|}{ Microscopy } \\
\hline Site of inflammation & Superficial & $\begin{array}{l}\text { Superficial and } \\
\text { submucosal }\end{array}$ & Transmural & & & \\
\hline $\begin{array}{l}\text { Inflammatory pattern } \\
\text { Submucosal thickening }\end{array}$ & $\begin{array}{l}\text { Continuous } \\
\text { Absent }\end{array}$ & $\begin{array}{l}\text { Aggregated } \\
\text { Slight }\end{array}$ & Moderate & Marked & & \\
\hline $\begin{array}{l}\text { Lymphoid aggregates } \\
\text { ( } 5 \text { sections) }\end{array}$ & 0 & $1-5$ & 6-10 & $11-20$ & $21-30$ & $>\mathbf{3 0}$ \\
\hline $\begin{array}{l}\text { Lymph follicles (with germinal } \\
\text { centres) ( } 5 \text { sections) }\end{array}$ & 0 & $1-5$ & 6-10 & $11-20$ & $>20$ & \\
\hline $\begin{array}{l}\text { Fissures ( } 5 \text { sections) } \\
\text { Polyps }\end{array}$ & $\begin{array}{l}0 \\
\text { Absent }\end{array}$ & $\begin{array}{l}1-5 \\
\text { Granulation }\end{array}$ & $\begin{array}{l}\text { 6-10 } \\
\text { Epithelial }\end{array}$ & $\begin{array}{l}\text { 11-15 } \\
\text { Adenomata }\end{array}$ & $16-20$ & $>20$ \\
\hline Glandular dysplasia & 0 & Slight & Moderate & Severe & & \\
\hline Intestinal metaplasia & 0 & Slight & Marked & & & \\
\hline $\begin{array}{l}\text { Glandular hyperplasia } \\
\text { Depth of ulceration }\end{array}$ & $\begin{array}{l}0 \\
\text { Absent }\end{array}$ & $\begin{array}{l}\text { Slight } \\
\text { Superficial } \\
\text { epithelium }\end{array}$ & $\begin{array}{l}\text { Marked } \\
\text { Full gland }\end{array}$ & Muscle necrosis & & \\
\hline Spacing of glands & Normal & $\begin{array}{l}\text { Slight to } \\
\text { moderate increase }\end{array}$ & Marked & & & \\
\hline Pattern of glands & Regular & $\begin{array}{l}\text { Slight to } \\
\text { moderate, } \\
\text { irregular }\end{array}$ & Marked & & & \\
\hline Height of glands & Normal & $\begin{array}{l}\text { Slight to } \\
\text { moderate, } \\
\text { shortening }\end{array}$ & Marked & & & \\
\hline $\begin{array}{l}\text { Crypt abscesses ( } 5 \text { sections) } \\
\text { Crypt dilatations ( } 5 \text { sections) }\end{array}$ & $\begin{array}{l}\mathbf{0} \\
\mathbf{0}\end{array}$ & $\begin{array}{l}1-10 \\
1-10\end{array}$ & $\begin{array}{l}11-25 \\
11-25\end{array}$ & $\begin{array}{l}26-40 \\
26-40\end{array}$ & $\begin{array}{l}41-60 \\
41-60\end{array}$ & $\begin{array}{l}>60 \\
>60\end{array}$ \\
\hline $\begin{array}{l}\text { Crypt abscesses with mucosal } \\
\text { lymph aggregates ( } 5 \text { sections) }\end{array}$ & 0 & $1-5$ & 6-10 & $11-20$ & $>20$ & \\
\hline
\end{tabular}

Table I Pathological features of the colitides and the method of grading 
one of six possible alternatives.

Most of the features are self explanatory, but a few points perhaps need to be clarified. In the category 'the character of the mucosa in the diseased area', by the term 'healed granular' we mean a non-ulcerated mucosa which does show a loss of mucosal folds and a 'morocco-leather-like' appearance. 'Superficial discrete ulcers', often circular and less than $3 \mathrm{~cm}$ in diameter, are separated by intact mucosa, whereas 'irregular confluent ulcers' often extend in a serpiginous fashion throughout the length of the disease. 'Linear confluent ulcers' show a distinct parallel directionalism along the axis of the bowel, although they are by no means smoothly outlined. They may be seen in exaggerated form as 'deep fissures' or with fine crevices running transversely between

\begin{tabular}{|c|c|c|c|c|c|c|}
\hline & \multicolumn{6}{|l|}{ Grade } \\
\hline & 1 & 2 & 3 & 4 & 5 & 6 \\
\hline \multicolumn{7}{|l|}{ Microscopy } \\
\hline $\begin{array}{l}\text { Ulcerated lymph aggregates } \\
\text { (5 sections) }\end{array}$ & $\mathbf{0}$ & $1-5$ & $6-10$ & $11-20$ & $>20$ & \\
\hline Mucosal cellularity & Normal & Slight increase & Moderate & Marked & & \\
\hline Mucosal cell type & Normal & $\begin{array}{l}\text { Lymphocytes } \\
\text { and plasma cells }\end{array}$ & $\begin{array}{l}\text { Lymphoid cells } \\
\text { and polymorphs }\end{array}$ & $\begin{array}{l}\text { Lymphoid cells } \\
\text { and histiocytes }\end{array}$ & & \\
\hline Eosinophils & Normal & Increased & & & & \\
\hline Submucosal cellularity & Normal & Slight increase & Moderate & Marked & & \\
\hline Submucosal cell type & Normal & $\begin{array}{l}\text { Lymphoid cells } \\
\text { and polymorphs }\end{array}$ & Lymphoid & $\begin{array}{l}\text { Lymphoid and } \\
\text { histiocytic }\end{array}$ & \multicolumn{2}{|l|}{$\begin{array}{l}\text { Predominant } \\
\text { histiocyte and } \\
\text { fibroblast }\end{array}$} \\
\hline Numbers of histiocytes & Normal & Slight increase & Many & Many transmural & & \\
\hline $\begin{array}{l}\text { Epithelioid cell follicles } \\
\text { ( } 5 \text { sections) }\end{array}$ & 0 & $1-5$ & 6-10 & $11-20$ & $21-30$ & $>30$ \\
\hline $\begin{array}{l}\text { Sarcoid-like granulomata } \\
\text { (5 sections) }\end{array}$ & $\mathbf{0}$ & $1-3$ & 4- 6 & $7-10$ & $11-20$ & $>20$ \\
\hline Vascularity & Normal & $\begin{array}{l}\text { Moderate } \\
\text { increase }\end{array}$ & Marked increase & & & \\
\hline Lymphangiectasia & Absent & Slight & Marked & & & \\
\hline Submucosal oedema & Absent & Present & & & & \\
\hline Muscularis mucosae & Thin & Normal & Thick & & & \\
\hline Submucosal oedema & Absent & Present & & & & \\
\hline Neuronal changes & Normal & $\begin{array}{l}\text { Numerous } \\
\text { bundles and/or } \\
\text { ganglia }\end{array}$ & $\begin{array}{l}\text { Neurofibro- } \\
\text { matoid change- }\end{array}$ & & & \\
\hline Arteritis & Absent & Present & & & & \\
\hline Paneth cells in colon & Absent & A few present & Numerous & & & \\
\hline Fibrin & Absent & Present & & & & \\
\hline $\mathbf{Z N}$ & Negative & Positive & & & & \\
\hline $\begin{array}{l}\text { Submucosal fibrosis } \\
\text { Mast cells }\end{array}$ & $\begin{array}{l}\text { Normal } \\
\text { Reduced }\end{array}$ & $\begin{array}{l}\text { Slight } \\
\text { Normal }\end{array}$ & $\begin{array}{l}\text { Moderate } \\
\text { Increased }\end{array}$ & Marked & & \\
\hline $\begin{array}{l}\text { Mucosal argentaffin cells } \\
\text { ( } 2 \text { sections) }\end{array}$ & $0-10$ & $11-20$ & $21-40$ & $41-70$ & $71-100$ & $>100$ \\
\hline Reticulin (base of tubules) & Intact & Disturbed & & & & \\
\hline $\begin{array}{l}\text { Glandular mucin } \mathbf{H} \text { and } E \\
\text { Gland mucin aldehyde fuchsin }\end{array}$ & $\begin{array}{l}\text { Increased } \\
\text { Reduced }\end{array}$ & $\begin{array}{l}\text { Normal } \\
\text { Normal }\end{array}$ & $\begin{array}{l}\text { Slight decrease } \\
\text { Increased }\end{array}$ & Partial decrease & Subtotal decroase & Total decrease \\
\hline Gland mucin alcian blue & Reduced & Normal & Increased & & & \\
\hline $\begin{array}{l}\text { Gland mucin PAS } \\
\text { PAS muciphages in lamina } \\
\text { propria }\end{array}$ & $\begin{array}{l}\text { Reduced } \\
\text { Normal }\end{array}$ & $\begin{array}{l}\text { Normal } \\
\text { Increased }\end{array}$ & $\begin{array}{l}\text { Increased } \\
\text { Decreased }\end{array}$ & & & \\
\hline $\begin{array}{l}\text { PAS staining in granulomata } \\
\text { Appendix }\end{array}$ & $\begin{array}{l}\text { No granulomata } \\
\text { Absent }\end{array}$ & $\begin{array}{l}\text { Negative } \\
\text { Normal }\end{array}$ & $\begin{array}{l}\text { Positive } \\
\text { Acute }\end{array}$ & Histiocytic & Granulomata & \\
\hline & & & & inflammation & & \\
\hline Anal canal & Absent & Normal & $\begin{array}{l}\text { Acute } \\
\text { inflammatory }\end{array}$ & $\begin{array}{l}\text { Chronic } \\
\text { inflammatory }\end{array}$ & Histiocytosis & Granulomatous \\
\hline Lymph nodes (total no.) & $1-10$ & $11-20$ & $21-30$ & $31-40$ & & \\
\hline Lymph node sinus catarrh $(\%)$ & 0 & $1-20$ & $21-40$ & $41-60$ & $61-80$ & $81-100$ \\
\hline $\begin{array}{l}\text { Lymph node follicular } \\
\text { hyperplasia }(\%)\end{array}$ & $\mathbf{0}$ & $1-20$ & $21-40$ & $41-60$ & $61-80$ & $81-100$ \\
\hline $\begin{array}{l}\text { Lymph node sinus } \\
\text { histiocytosis }(\%)\end{array}$ & $\mathbf{0}$ & $1-20$ & $21-40$ & $41-60$ & $61-80$ & $81-100$ \\
\hline Epithelioid cell follicles (\%) & $\mathbf{0}$ & $1-20$ & $21-40$ & $41-60$ & $61-80$ & $81-100$ \\
\hline $\begin{array}{l}\text { LN sarcoid-like granulomata } \\
(\%)\end{array}$ & 0 & $1-20$ & $21-40$ & $41-60$ & $61-80$ & $81-100$ \\
\hline $\begin{array}{l}\text { Lymph nodes follicular } \\
\text { reticulin }\end{array}$ & Abundant & Sparse or absent & & & & \\
\hline Diagnosis & Ulcerative colitis & Crohn's & $\begin{array}{l}\text { Atypical } \\
\text { ulcerative colitis }\end{array}$ & Atypical Crohn's & & \\
\hline Previous clinical diagnosis & Ulcerative colitis & Crohn's & & & & \\
\hline
\end{tabular}


nodular elevations of mucosa thus forming a 'cobblestone' effect.

We included in the category of 'epithelioid cell follicles' collections of histiocytes or epithelioid cells even when rather small and ill defined, whereas the category of 'sarcoid-like granulomata' was reserved for well defined follicles of epithelioid cells complete with multinucleate giant cells of Langhan's type. 'Crypt dilatations', a reflection of glandular irregularity, are flask-shaped empty glands often with depleted mucin.

Before the study began the two observers worked together for a time to familiarize themselves with the conventions. During the actual study each observer was unaware both of the previous diagnosis of each specimen and of the other pathologist's verdict. The data were recorded by filling in a blank version of table I for each case and each pathologist.

Five sections for detailed microscopic study were selected during macroscopic examination of the specimen from diseased areas in the large bowel and special stains-aldehyde fuchsin, alcian blue, periodic acid Schiff, Martius scarlet blue, diazo reaction for argentaffin granules, Ziehl Neelsen, reticulin (Gordon and Sweet)-were performed on these five sections in order to demonstrate certain histological features.

Representative haematoxylin-and-eosin-stained sections from all other parts of the specimen were also examined.

The observations were stored and correlated on a Jason suite of data preparation programs implemented on an English Electric KDF9 computer.

\section{Results}

The data contained on the two completed forms per patient were used to compare the observations of the two pathologists. A $100 \%$ agreement not only indicated agreement on the presence or absence of a feature but also showed that the same grading of severity or type was recorded. The percentage agreement of the observations of a feature was calculated as a proportion of the total positive incidence of that feature rather than of the number of cases in the series, ie, 50 . Observer agreement of $90 \%$ and over was regarded as very accurate and between $\mathbf{7 0}$ and $90 \%$ as moderately so. Many observations were found to be accurate only when the grading was made less fine and in the analysis of the data many of the original groups were retrospectively amalgamated.

Table II shows those features for which the observers' agreement was moderate or good. The remainder, including such commonly used features as cobblestoning and lymphangiectasis, had less than $70 \%$ agreement. Table II also shows how some grades were fused together to attain better agreement.

A correlation was also made between the pathological observations of the senior author (M.G.C) and the diagnoses of the 42 cases in which both observers and the previous clinical diagnoses were

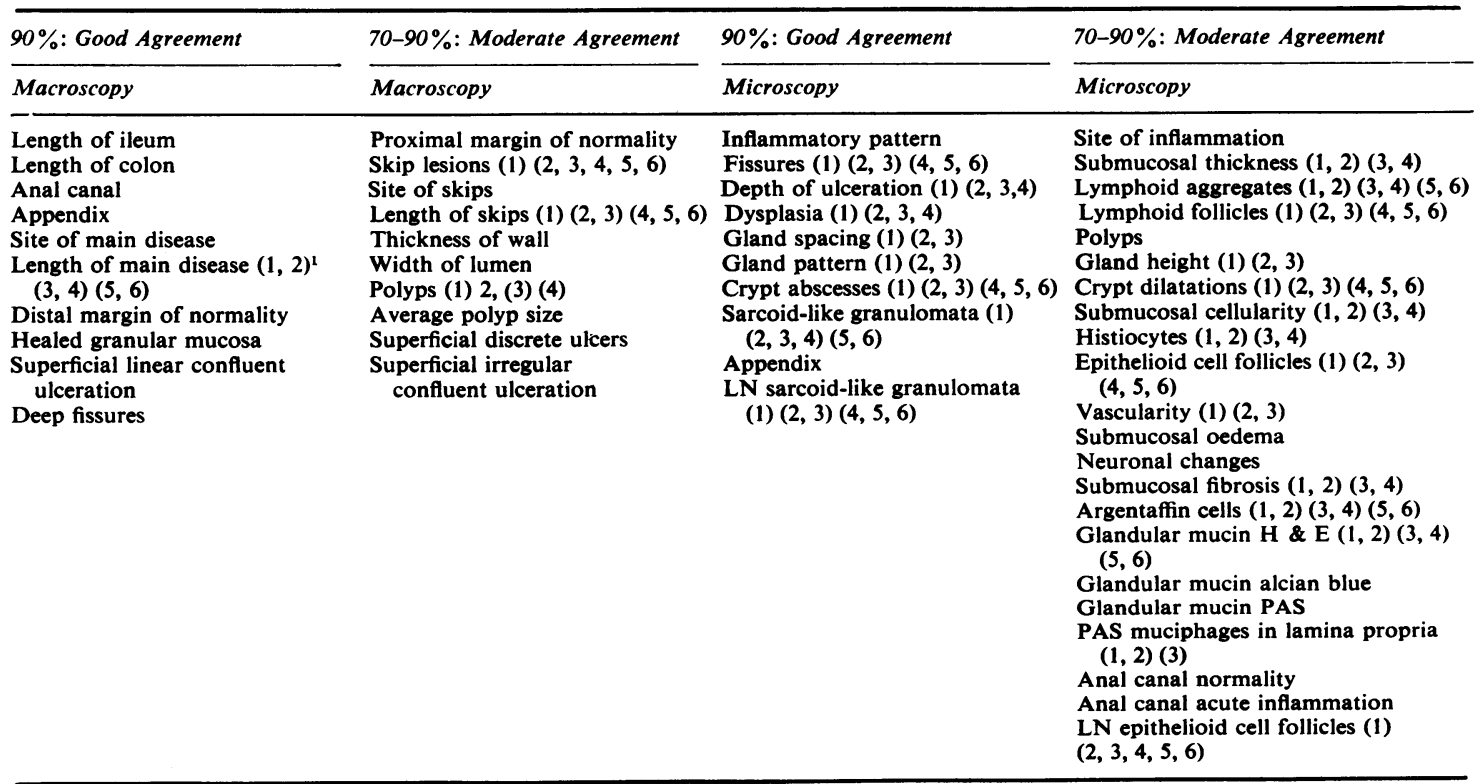

Table II Observer variation in grading of pathological features of the colitides

'Figures within brackets refer to column numbers in table $I$ and indicate how the grades have been amalgamated to produce better agreement. 
all in agreement, thereby ensuring that those cases were all entirely typical. This gave an assessment of the value of these features in the differential diagnosis. Fisher's exact probability test was used with Tocher's modification to compare the incidence of each observation in the two diseases. This enabled tables III and IV to be made, in which the observations which had a significantly different incidence in ulcerative colitis and Crohn's disease are listed with their corresponding significance. Eight cases were not included in the correlation of observations and diagnoses. Of these one case was excluded because the firm clinical diagnosis was Crohn's disease, but both pathologists diagnosed ulcerative colitis. The other seven cases were excluded because the pathologists were not able to classify them confidently although they were able to indicate which form they most resembled. Of four cases diagnosed pathologically as atypical ulcerative colitis, two were clinically ulcerative colitis and two were previously called Crohn's disease. Similarly the three cases labelled pathologically as atypical Crohn's disease had all been regarded clinically as Crohn's disease.

Some pathological changes were not seen in the series-these were acid-fast bacilli and adhesionsand, therefore, they have not been included in any of the tables subsequent to table I. PAS positivity of granulomata was also excluded because it was invariably present and merely reflected the incidence of granulomata which could in any case be accurately recorded.

\section{Discussion}

There is a range of appearances in inflammatory diseases of the colon which form a continuous spectrum, the ends of which are easily labelled as either ulcerative colitis or Crohn's disease. Between these extremes any given feature may vary in frequency or severity and independently of the other pathological changes. This results in an infinite number of pathological appearances and great difficulty in separating the diseases into pathological

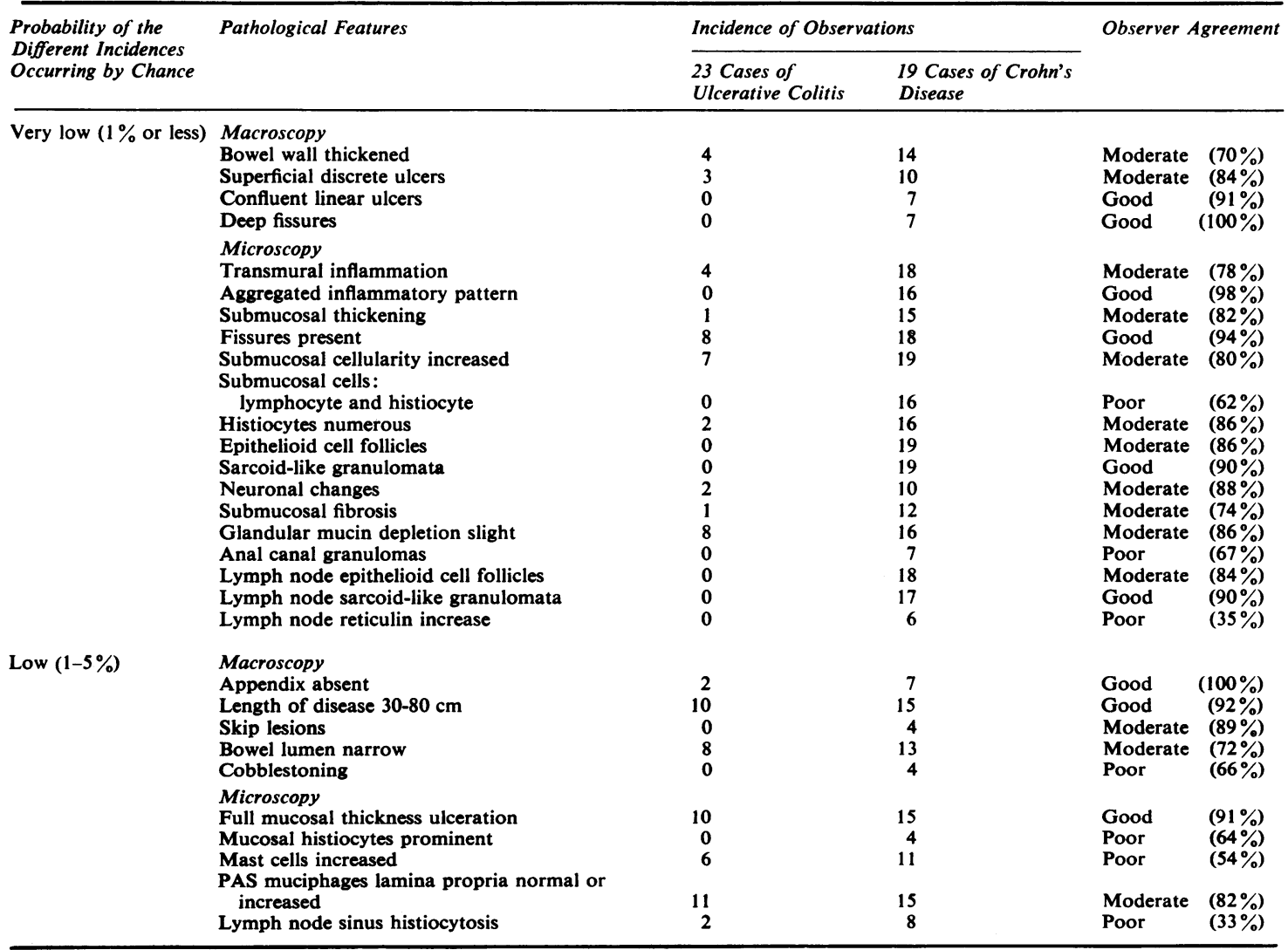




\begin{tabular}{|c|c|c|c|c|c|}
\hline \multirow{2}{*}{$\begin{array}{l}\text { Probability of the } \\
\text { Different Incidences } \\
\text { Occurring by Chance }\end{array}$} & \multirow[t]{2}{*}{ Pathological Features } & \multicolumn{2}{|c|}{ Incidence of Observations } & \multicolumn{2}{|c|}{ Observer Agreement } \\
\hline & & $\begin{array}{l}23 \text { Cases of } \\
\text { Ulcerative Colitis }\end{array}$ & $\begin{array}{l}19 \text { Cases of Crohn's } \\
\text { Disease }\end{array}$ & & \\
\hline \multirow[t]{2}{*}{ Very low ( $1 \%$ or less) } & $\begin{array}{l}\text { Macroscopy } \\
\text { Length of disease }>80 \mathrm{~cm} \\
\text { Bowel wall of normal thickness } \\
\text { Healed granular mucosa }\end{array}$ & $\begin{array}{l}13 \\
17 \\
12\end{array}$ & $\begin{array}{l}2 \\
4 \\
0\end{array}$ & $\begin{array}{l}\text { Good } \\
\text { Moderate } \\
\text { Good }\end{array}$ & $\begin{array}{l}(92 \%) \\
(70 \%) \\
(92 \%)\end{array}$ \\
\hline & $\begin{array}{l}\text { Microscopy } \\
\text { Superficial inflammation } \\
\text { Superficial and submucosal inflammation } \\
\text { Continuous inflammatory pattern } \\
\text { Submucosal thickening absent or slight } \\
\text { Fissures absent } \\
\text { Gland pattern irregular } \\
\text { Gland height reduced } \\
\text { Submucosal cellularity normal or slight increase } \\
\text { Submucosal inflammatory cells mainly lymphoid } \\
\text { Histiocytes normal or only slightly increased } \\
\text { Submucosal fibrosis normal or slight } \\
\text { Anal canal normal }\end{array}$ & $\begin{array}{l}7 \\
12 \\
23 \\
22 \\
15 \\
23 \\
18 \\
16 \\
15 \\
21 \\
22 \\
16\end{array}$ & $\begin{array}{r}0 \\
1 \\
3 \\
4 \\
1 \\
13 \\
7 \\
0 \\
1 \\
3 \\
7 \\
2\end{array}$ & $\begin{array}{l}\text { Moderate } \\
\text { Moderate } \\
\text { Good } \\
\text { Moderate } \\
\text { Good } \\
\text { Good } \\
\text { Moderate } \\
\text { Moderate } \\
\text { Poor } \\
\text { Moderate } \\
\text { Moderate } \\
\text { Moderate }\end{array}$ & $\begin{array}{l}(78 \%) \\
(78 \%) \\
(98 \%) \\
(82 \%) \\
(94 \%) \\
(92 \%) \\
(82 \%) \\
(80 \%) \\
(62 \%) \\
(86 \%) \\
(74 \%) \\
(84 \%)\end{array}$ \\
\hline \multirow[t]{3}{*}{ Low $(1-5 \%)$} & $\begin{array}{l}\text { Macroscopy } \\
\text { Anal canal normal } \\
\text { Total large bowel disease }\end{array}$ & $\begin{array}{l}12 \\
13\end{array}$ & $\begin{array}{l}3 \\
4\end{array}$ & $\begin{array}{l}\text { Good } \\
\text { Good }\end{array}$ & $\begin{array}{l}(96 \%) \\
(98 \%)\end{array}$ \\
\hline & $\begin{array}{l}\text { Microscopy } \\
\text { Dysplasia } \\
\text { Gland spacing increased } \\
\text { Submucosal inflammatory cells: lymphoid and }\end{array}$ & $\begin{array}{l}15 \\
23\end{array}$ & $\begin{array}{r}5 \\
15\end{array}$ & $\begin{array}{l}\text { Good } \\
\text { Good }\end{array}$ & $\begin{array}{l}(92 \%) \\
(92 \%)\end{array}$ \\
\hline & $\begin{array}{l}\text { polymorphs } \\
\text { Muscularis mucosae thinned } \\
\text { Mast cells reduced } \\
\text { Gland mucin severely depleted } \\
\text { PAS muciphages in lamina propria reduced }\end{array}$ & $\begin{array}{r}7 \\
7 \\
9 \\
8 \\
12\end{array}$ & $\begin{array}{l}1 \\
1 \\
1 \\
1 \\
4\end{array}$ & $\begin{array}{l}\text { Poor } \\
\text { Poor } \\
\text { Poor } \\
\text { Moderate } \\
\text { Moderate }\end{array}$ & $\begin{array}{l}(62 \%) \\
(56 \%) \\
(54 \%) \\
(86 \%) \\
(82 \%)\end{array}$ \\
\hline
\end{tabular}

Table IV Observations useful in the diagnosis of ulcerative colitis

entities (Schachter, Goldstein, Rappaport, Fennessy, and Kirsner, 1970; Glotzer, Gardner, Goldman, Hinrichs, Rosen, and Zetzel, 1970).

By concentrating on those points which correlate most often with clinical impression it has been possible to define the classical clinico-pathological types and to adopt a rather casuistical approach towards the atypical cases, classifying them either according to the clinical impressions or by allowing a few pathological features to assume more importance when need arises.

The resulting confusion and imprecision mean that many patients allocated to a single diagnostic categorydo not share a homogeneous pathological picture and this probably explains why experimental work in these diseases is so inconsistent (Kraft, 1971). The great need is for pathologists to describe cases in detail without clinical opinion prejudicing their reporting and to concentrate less on forcing the case before them into a largely clinically defined category.

The situation is made more complex because there in inevitably some variation in the accuracy of observation of different pathological features. A feature may be thought to be useful but may be so difficult to define or observe that one pathologist's assessment of that point may differ from that of other pathologists. For this reason we have set out initially to establish, at least in typical cases, which features can be accurately recorded and similarly interpreted by other pathologists before assessing the value of those same features in reaching independently an identical diagnosis to that of the clinician. Having established those features which can be accurately observed, it would be helpful in prospective work to record all such features in unselected cases, including atypical ones, and establish any correlations there might be between the pathological features and clinical and radiological findings. This may reveal those features or pattern of features which are distinctive of one or other of the two diseases. We do not now suggest that only those features listed in tables II, III, and IV as both useful and accurate should be used, since this whole study is based on cases selected for their typicality. The results, however, indicate those features which can be given greatest reliance. It is also possible that an individual pathologist can reproducibly record some features which are not similarly interpreted by other pathologists. Nevertheless, diagnosis of typical cases should be based on features of significant value, as in tables III and IV, bearing in mind the likely inaccuracy in observation of each feature and the varying pattern of incidence that occurs while still remaining highly significantly different. For example, 
while the incidence of fissures and granulomata is significantly different in the two diseases, the numbers concerned for fissures are eight and 18 and for granulomata 0 and 19 in ulcerative colitis and Crohn's disease respectively.

An individual pathologist may subsequently find that he is accurate in his own observation of a particular point not listed as having good observer agreement and thus place more weight on this if it is diagnostically valuable.

Although overlapping of the appearances of ulcerative colitis and Crohn's disease is accepted (Lumb and Prothero, 1958; Glotzer et al, 1970; Schachter et al, 1970), this does not necessarily imply a unitary disease entity but merely indicates that some pathological changes are common to both diseases and that the essential features or combination of features which distinguish one disease from the other have not been defined or accepted.

Ultrastructural evidence has been provided to support the concept of Crohn's disease being a single disease entity distinct from ulcerative colitis by Turnbull and Cook (1973), who pointed to the neuronal hyperplasia, predominant lymphocyte infiltration, and relatively undisturbed epithelium as consistent features of Crohn's disease but not of ulcerative colitis. These same points were seen not only in the granulomatous Crohn's cases but in those cases free of granulomata which constitute about $40 \%$ of the total (Williams, 1964; Morson, 1971; Cook, 1972).

In the present study neuronal changes, previously reported by Davis et al (1955), and relatively unchanged epithelia were also found more frequently in Crohn's disease than in ulcerative colitis, the difference being highly significant. Both features were recognized with great reliability by the two pathologists.

It can be seen from tables III and IV that other features show a highly significant difference in incidence in the two diseases and are also highly accurately recorded. These include confluent linear ulceration, macroscopic deep fissures, an aggregated pattern of inflammation, and sarcoid-like granulomata as indications of Crohn's disease, and a 'healed granular' mucosa, the absence of fissures, irregular glands, and a continuous pattern of inflammation as pointing to ulcerative colitis. Some features such as cobblestoning of the mucosa and numbers of mast cells, although of significantly different incidence in the two diseases, were not consistently observed by both pathologists. Still other features previously reported as helpful in differential diagnosis, such as crypt abscesses, lymphangiectasia, submucosal oedema, and changes in the glandular reticulin pattern (Mottet, 1971), did not have a significantly different incidence in the two diseases. Likewise we contradict the implication by Watkinson, Thompson, and Goligher (1960), Saltzstein and Rosenberg (1963), and Schachter et al (1970) that granulomata can be found in ulcerative colitis. This feature was invariably accurately observed and a constant indicator of Crohn's disease.

This preliminary study seems to indicate that by accurate observation of a wide range of pathological parameters it may become possible to clarify the middle ground of the colitides and we have shown that some features can be relied on more than others. Correlation of these accurately observed features with clinical data may eventually confirm Crohn's disease as a syndrome comprising a number of diseases as suggested by Hywel-Jones, Card, Chapman, Lennard-Jones, Morson, Sackin, and Sneath (1970) or indicate that it is a single entity as suggested by clinical impression and supported to some extent by ultrastructural observations. It may well be that the whole spectrum of ulcerative colitis and Crohn's disease represents the effects of two aggressive processes, one humoral and the other granulomatous, the importance of each varying from case to case.

We are very grateful to Professor J. C. Goligher for access to the abundant pathological material in his department and for his constructive advice. We are also indebted to Mr F. T. de Dombal and his unit for their essential service of data processing, to $\mathrm{Mr}$ R. J. Wilson for his application of statistical analysis to the data, and to Miss Pamela Skidmore and Mrs D. Sawdon for technical and secretarial help.

This work was supported by the Endowment Fund of the General Infirmary, Leeds.

\section{References}

Cook, M. G. (1972). The size and histological appearances of mesenteric lymph nodes in Crohn's disease. Gut, 13, 970-972.

Davis, D. R., Dockerty, M. B., and Mayo, C. W. (1955). The mesenteric plexus in regional enteritis: a study of the number of ganglion cells in the ileum in 24 cases. Surg. Gynec. Obstet., 101, 208-216.

Filipe, M. I., and Dawson, I. M. P. (1970). The diagnostic value of mucosubstances in rectal biopsies from patients with ulcerative colitis and Crohn's disease. Gut, 11, 229-234.

Glotzer, D. J., Gardner, R. C., Goldman, H., Hinrichs, H. R., Rosen, H., and Zetzel, L. (1970). Comparative features and course of ulcerative and granulomatous colitis. New Engl. J. Med., 282, 582-587.

Hywel-Jones, J., Card, W., Chapman, M., Lennard-Jones, J. E., Morson, B. C., Sackin, M. J., and Sneath, P. H. A. (1970). The application of numerical taxonomy to the separation of colonic inflammatory diseases. In Advance Abstracts, 4th World Congress of Gastroenterology, Copenhagen, edited by P. Riis, P. Anthonisen, and H. Baden. Danish Gastroenterological Association, Copenhagen.

Kent, T. H., Ammon, R. K., and DenBesten, L. (1970). Differentiation of ulcerative colitis and regional enteritis of colon. Arch. Path., 89, 20-29.

Kraft, S. C. (1971). Cellular immunity in Crohn's disease. Gastroenterology, 61, 545-548.

Lennard-Jones, J. E., Lockhart-Mummery, H. E., and Morson, B. C. (1968). Clinical and pathological differentiation of Crohn's disease and proctocolitis. Gastroenterology, 54, 1162-1170. 
Lumb, G., and Protheroe, R. H. B. (1958). Ulcerative colitis: a pathologic study of 152 surgical specimens. Gastroenterology, 34, $381-407$.

McGovern, V. J. (1969). The differential diagnosis of colitis. In The Pathology Annual, S. C. Sommers, Vol. 4, pp. 127-158.

Montes, M., Milch, E., Berman, L., Culver, G. J. (1971). Chronic ulcerative disease of the colon. Dis. Colon Rect., 14, 117-122.

Morson, B. C. (1968). Pathology. In Ulcerative colitis edited by J. C. Goligher, F. T. de Dombal, J. McK. Watts, and G. Watkinson, ch. 2, pp. 5-31, Baillière, London.

Morson, B. C. (1971). Histopathology of Crohn's disease Scand. J. Gastroent., 6, 573-575.

Mottet, N. K. (1971). Histopathologic Spectrum of Regional Enteritis and Ulcerative Colitis, ch. 4 and 5, pp. 63-154, Philadelphia.

Rappaport, H., Burgoyne, F. H., and Smetana, H. F. (1951). The pathology of regional enteritis. Milit. Surg., 109, 463-502.

Saltzstein, S. L., and Rosenberg, B. F. (1963). Ulcerative colitis of the ileum and regional enteritis of the colon. Amer. J. clin. Path., 40, 610-623.

Schachter, H., Goldstein, M. J., Rappaport. H., Fennessy, J. J., and Kirsner, J. B. (1970). Ulcerative and 'granulomatous' colitisvalidity of differential diagnostic criteria. Ann. intern. Med., 72, 841-851.

Skinner, J. M., Whitehead, R., and Piris, J. (1971). Argentaffin cells in ulcerative colitis. Gut, 12, 636-638.

Turnbull, G. J., Cook, M. G. (1973). The ultrastructure of Crohn's disease and its differentiation from ulcerative colitis. (To be published).

Van Patter, W. N., Bargen, J. A., Dockerty, M. B., Feldman, W. H., Mayo, C. W., and Waugh, J. M. (1954). Regional enteritis. Gastroenterology, 26, 347-450.

Watkinson, G., Thompson, H., and Goligher, J. C. (1960). Rightsided or segmental ulcerative colitis. Brit. J. Surg., 47, 337-351.

Williams, W. J. (1964). Histology of Crohn's syndrome. Gut, 5, 510-516. 